\section{Virus, aper, blod og prostitusjon}

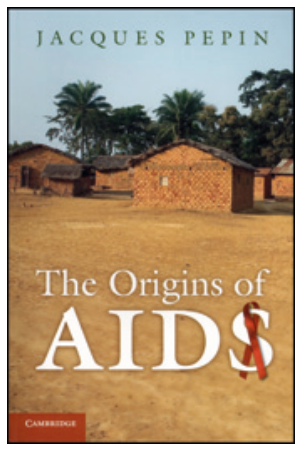

\section{Jacques Pepin \\ The origins of AIDS}

293 s, tab, ill. Cambridge: Cambridge University Press, 2011. Pris GBP 18

ISBN 978-0-521-18637-7

Temaet er hivvirusenes opprinnelse og de mange kompliserte virologiske, epidemiologiske, sosiale og kulturelle mekanismene som sammen førte til aidspandemien. Fra sin start i Sentral-Afrika er pandemien i dag global.

Jacques Pepin er professor i infeksjonsmedisin ved Université de Sherbrooke i Canada. Han har i mange år arbeidet i afrikanske land både som forsker og kliniker, og har slik fått en betydelig innsikt i afrikanske forhold, også i kolonitiden. Pepin baserer seg i betydelig grad på andre forskeres arbeid på feltet, men yter også selv viktige bidrag, bl.a. ved sine studier av arkiver fra kolonitiden.

Man antar at begge de to hovedtypene av hiv, hiv-1 som er ansvarlig for pandemien, og hiv-2 som i alt vesentlig finnes i VestAfrika, stammer fra beslektede apevirus. Disse virusene, SIV (simian immunodeficiency virus), forekommer naturlig hos mange sentralafrikanske apearter. Man regner med at hiv-1 nedstammer fra en SIV-type som finnes hos sjimpanser, mens hiv-2 stammer fra et annet SIV hos «sooty mangabeys». Pepin redegjør i detalj for de aktuelle apeartenes forekomst og atferd og beskriver de mange sofistikerte molekylærbiologiske studiene av SIV og hiv som i betydelig grad sannsynliggjør hypotesen om relasjonen mellom SIV og hiv.

SIV har trolig eksistert hos aper i århundrer, mens svært mye tyder på at overgangen av virus fra ape til menneske har skjedd i det 20. århundre, for hiv-1 kanskje rundt 1920, og noen tiår senere for hiv-2. Hvorfor eksploderte så den afrikanske aidsepidemien først i 1970-årene? Her er Pepins egen teori som han baserer på studier av medisinsk praksis i kolonitiden, at hivepidemien fikk en «jump start» gjennom iatrogen spredning via intravenøse injeksjoner med usterilisert injeksjonsutstyr som trolig tidligere var regelen, og ikke unntaket, i Sentral-Afrika. Så akselererte hivepidemien etter hvert gjennom heteroseksuell smitteoverføring, godt hjulpet av andre seksuelt overførbare infeksjoner. Dette skjedde imidlertid først da store sosiologiske og kulturelle endringer, bl.a. i forbindelse med migrasjon og urbanisering, endret seksuelle atferdsmønstre og førte til omfattende prostitusjon.

Forfatteren skisserer så videre hvordan han at mener hiv spredte seg fra Afrika til resten av verden. Mye tyder på at epidemien slo til på Haiti noen få år før den for alvor rammet USA. Han postulerer at viruset ble brakt til Haiti fra det kriserammede Kongo i 1960-årene med en av de 4500 FN-ansatte hjelpearbeiderne fra Haiti. Spredningen på Haiti var nok i betydelig grad seksuell, men Pepin mener at nokså lyssky plasmaproduksjon under Papa Doc (1907-71) i vesentlig grad har bidratt i startfasen. Viruset ble så brakt videre til USA med amerikanske homofile turister som i betydelig grad benyttet Haiti som feriemål. Fra USA spredte viruset seg til Europa og resten av verden, initialt via homoseksuell turisme.

Dette er utvilsomt den mest informative og oppdaterte tilgjengelige fremstillingen av bakgrunnen og den tidlige historien til aidsepidemien. I dette kompliserte puslespillet plasserer forfatteren de fleste brikkene på en overbevisende måte, selv om han, der brikkene mangler, fyller ut bildet mer spekulativt. Hans styrke gjelder særlig innsikten i afrikanske forhold og medisinsk praksis i koloni- tiden. Det skal imidlertid ikke underslås at fremstillingen i noen grad tynges av svært mange detaljer, om aper, fylogenetiske hivstudier og ikke minst politiske og medisinske aspekter i og etter kolonitiden. Derfor vil nok boken kanskje i særlig grad appellere til spesielt interesserte.

\section{Stig S. Frøland}

Seksjon for klinisk immunologi og infeksjonssykdommer Oslo universitetssykehus, Rikshospitalet

\section{Alt om generalisert angstlidelse i lommeformat}

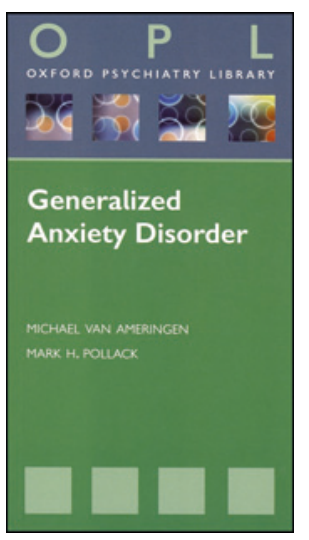

Michael Van Ameringen, Mark Pollack, red Generalized anxiety disorder

108 s, tab, ill. Oxford: Oxford University Press, 2012. Pris GBP 13

ISBN 978-0-19-955783-7

Boken er i lommeformat og inneholder åtte kapitler fordelt på 108 små sider. Angstlidelsens diagnose og forekomst, kliniske kjennetegn, nevrobiologi, farmakoterapi, psykoterapi, klinisk håndtering og selvhjelpsressurser omtales. I tillegg finnes en samling av de mest brukte skåringsverktøyene for lidelsen.

Forfatternes intensjon er å kombinere en kortfattet oversikt over forskningsbasert viten om generalisert angstlidelse med praktiske terapianbefalinger. Det har de lyktes godt med.

Stoffet er meget ryddig presentert med nøkkelpoeng uthevet i begynnelsen av hvert kapittel. Tabellene er oversiktlige, og boken avsluttes med en rikholdig innholdsfortegnelse som gjør det enkelt å slå opp. Terapianbefalingene er, til tross for at hovedmarkedet er Nord-Amerika, hvor forfatterne også holder til, stort sett i tråd med de norske. Men mange med meg ville nok gjerne sett at hydroksizin var tatt inn i gruppen av førstehåndsmidler, mens benzodiazepinene ble flyttet over i gruppen av andrehåndsmidler.

Målgruppen er alle som trenger en innføring i eller kortfattet oppdatering om generalisert angstlidelse. Bokens styrke - at den er kortfattet - er selvfølgelig også dens svakhet, men de som får utløst leselyst vil finne alt de trenger i de fyldige referansene i slutten av hvert kapittel.

\section{Bjørn Ravneberg}

Oslo 